\title{
RDF Characterization for More Efficient Use in Combustion Systems ${ }^{\dagger}$
}

\author{
Radu Kuncser ${ }^{1,2}$, Marius Enache ${ }^{1,2}$, Septimiu Valasutean ${ }^{3}$, Malina Prisecaru ${ }^{1}$, Elena Pop ${ }^{1}$ and \\ Maria Paraschiv 1,4,* \\ 1 Faculty of Mechanical Engineering and Mechatronics, University POLITEHNICA of Bucharest, \\ 313 Splaiul Independentei, 060042 Bucharest, Romania; radu.kuncser@comoti.ro (R.K.); \\ marius.enache@comoti.ro (M.E.); malina.prisecaru@upb.ro (M.P.); elena.pop@upb.ro (E.P.) \\ 2 Romanian R\&D Institute for Gas Turbines -COMOTI, 220D Iuliu Maniu St., 061126 Bucharest, Romania \\ 3 S.C. VITALIA-Servicii Pentru Mediu S.A., 6 Poligonului Street, Boldesti Scaeni, 105300 Prahova, Romania; \\ septimiu.valasutean@vitalia-mediu.ro \\ 4 National Institute of R\&D for Biological Sciences, Department of Biomaterials and Bioproducts, \\ 296 Splaiul Independentei, 060042 Bucharest, Romania \\ * Correspondence: maria.paraschiv1504@upb.ro \\ + Presented at the 16th International Symposium "Priorities of Chemistry for a Sustainable Development" \\ PRIOCHEM, Bucharest, Romania, 28-30 October 2020.
}

Published: 16 November 2020

Keywords: solid municipal waste; pyrolysis; RDF

\section{Introduction}

The main systems for solid municipal waste (SMW) management involve the separation of all recyclable materials and the last fraction, usually named refuse-derived fuel (RDF), which contains all non-recyclable materials with different particle sizes and variable moisture, depending on the efficiency of the management system [1-3]. Usually, due to its convenient calorific value, the dried RFD is used in the cement industry for the partial replacement of solid fuels [1].

To answer specific issues in the Integrated Management Center from Tarpiu, Bistrita Nasaud County, through the CleanTech Project, funded under the frame of POC 2014-2020 Structural Funds Programme, a complete characterization of produced RDF is under evaluation.

\section{Materials and Methods}

In this study, the RDF recovered from SMW separation was decomposed in a fixed-bed reactor and the condensable fraction was analyzed be gas chromatography coupled with mass spectrometry (GC/MS) using a Perkin Elmer analyzer.

\section{Results}

The main compounds in the liquid phase collected during the thermochemical decomposition in an oxygen-free atmosphere of tested RDF were identified. In Figure 1, the chemical structure of these compounds and their retention time are presented. 


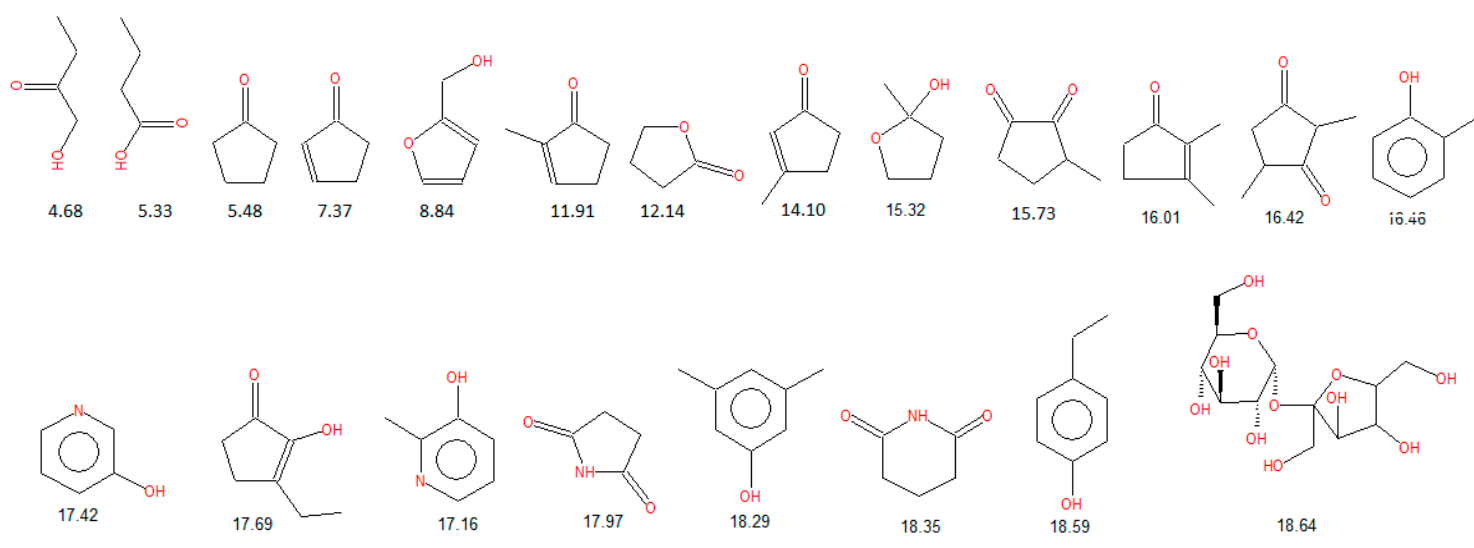

Figure 1. Main compounds identified by gas chromatography coupled with mass spectrometry (GC/MS).

\section{Conclusions}

By applying GC/MS analyses, the main compound released by the RDF in thermochemical applications can be identified, which allows a better control of post-treatment procedures efficiency.

Acknowledgments: This work was supported by the Romanian competitiveness operational program (POC 2014-2020) through the knowledge transfer project - CleanTech, POC-P40_308, SMIS: 105958 (http://cleantech.pub.ro/).

\section{References}

1. EUROPEAN COMMISSION-Joint Research Centre. Best Environmental Management Practice for the Waste Management Sector; Publications Office of the European Union: Luxembourg, 2018, doi:10.2760/50247.

2. Perrot, J.F.; Subiantoro, A. Municipal Waste Management Strategy Review and Waste-to-Energy Potentials in New Zealand. Sustainability 2018, 10, 3114.

3. Bugge, M.M.; Fevolden, A.M.; Klitkou, A. Governance for system optimization and system change: The case of urban waste. Res. Policy 2019, 48, 1076-1090.

Publisher's Note: MDPI stays neutral with regard to jurisdictional claims in published maps and institutional affiliations.

() 2020 by the authors. Licensee MDPI, Basel, Switzerland. This article is an open access article distributed under the terms and conditions of the Creative Commons Attribution (CC BY) license (http://creativecommons.org/licenses/by/4.0/). 